\title{
Influence of gender factor in the process of analyzing professional sec- toral personal identification (PSPI) of the leader
}

\author{
Alexandr Shatokhin ${ }^{1, *}$ \\ ${ }^{1}$ Federal State Budget Educational Institution of Higher Education «Volgograd State Agrarian University», 400002, Volgograd, Russia
}

\begin{abstract}
The article describes the features of the study of professional sectoral identification of a leader, taking into account the type of gender identification, temperament, style and management strategy. The paper presents the main results of the degree of professional sectoral identification of a manager. Today, issues of gender competition are the basis of the discussion platform throughout the world. Disputes about the influence of a gender factor on the organizational behavior of a manager do not fade away, but are only fueled by a growing public interest. Many see the gender factor as fundamental when choosing a manager's position. In this regard, the study of the influence of gender aspects as an essential component of a successful leader is a prerequisite for the effective functioning of not only companies, but also society as a whole. The relevance of the study of gender differences in the field of managerial activity is justified by the possibility of using the conceptual apparatus of personality psychology and management theory, which makes it possible to use the potential of gender relations as one of the reserves for increasing the efficiency of managerial activity. Gender features of personality behavior in management activities are manifested in management strategies and are one of the factors determining the implementation of the managerial role. The key criterion, eloquently characterizing the specifics of management activities, is the management style in relation to their subordinates, which largely determines the success and dynamics of the organization's development and on which the motivation of employees, their attitude to work, and relationships directly depend. In managerial practice, gender aspects encompass the characteristics of different approaches to the management of a team and a person, interpersonal relations, taking into account the male and female psyche and the characteristic features of intelligence.
\end{abstract}

\section{Introduction}

Issues of gender identification and management efficiency have long been in the focus of attention of researchers from different countries [1]. They were studied by such scientists as: Wollum Nielsen [2], Berloff G. [3], Gartzia L., \& Baniandrés J. [4], West K., Zimmerman D. [5], Repina T.A. [6], Radina N.K. [7,8], Kon I.S. [9], Aleshina Yu. E., Volovich A. S. [10], Erikson E. [12], Schneider L.B. [13].

Gender identity is an awareness of the connection with cultural definitions of masculinity and femininity, attributing oneself to male or female identity (special, equivalent, but different) and reproducing relevant gender-related roles and self-presentations. Traditionally, masculinity and femininity are the normative ideas about the psychological and behavioral properties characteristic of men and women. At the same time, it is possible to single out such a difference in the categories of masculinity and femininity as a result of the development of the symbolic culture of society, beliefs, and beliefs.

\section{Materials and methods}

It is important to carry out a study of professional sectoral personal identification of a leader (PSPI), not only taking into account temperament, type of profession, but also taking into account gender factors such as gender personality, personality self-realization strategy. In the process of research, two main strategies of self-realization of the individual were used: spiritually oriented and materially oriented. The first professional strategy of self-realization of the individual involves maintaining a certain level of professional sectoral identification, due to the general life orientation of being with a predominance of spiritual values (personal professional growth, spiritual development, etc.). The second professional strategy of self-realization of a person presupposes the achievement of material values. Individuals whose professional strategy of self-realization with a focus on spiritual values prevails, the risk of reducing of professional sectoral personal identification is less than that of individuals, with the prevailing professional strategy of self-realization with a focus on material values.

\footnotetext{
* Corresponding author: schlaf@bk.ru
} 


\section{Results}

The degree of professional sectoral identification of a manager depending on temperament, style of management with consideration of gender factor will be presented in Table 1.
The gender factor will be considered taking into account the completeness of identification. We single out individuals with full and partial male identification, with full and partial female identification. That is, women with partial masculinity and men with partial femininity.

Table 1. The degree of professional sectoral personal identification (PSPI) of managers with regard to gender, temperament and management style

\begin{tabular}{|c|c|c|c|c|c|}
\hline \multirow[t]{2}{*}{ № } & \multirow{2}{*}{ Temperament } & \multicolumn{2}{|c|}{ Men's identification } & \multicolumn{2}{|c|}{ Female identification } \\
\hline & & full & partial & full & partial \\
\hline \multicolumn{6}{|c|}{ Command and management style } \\
\hline 1. & Choleric person & $\mathrm{S}$ & $\mathrm{R}$ & $\mathrm{S}, \mathrm{R}$ & $\mathrm{S}$ \\
\hline 2. & Sanguine person & $\mathrm{S}$ & $\mathrm{R}, \mathrm{N}$ & $\begin{array}{c}\mathrm{R}, \mathrm{S} \\
\text { (fragmentary) }\end{array}$ & $\mathrm{S}, \mathrm{R}$ \\
\hline 3. & Phlegmatic person & $\mathrm{S}$ & $\mathrm{R}, \mathrm{N}, \mathrm{L}$ & $\mathrm{S}, \mathrm{N}$ & $\mathrm{S}, \mathrm{R}, \mathrm{N}$ \\
\hline 4. & $\begin{array}{l}\text { Melancholic } \\
\text { person }\end{array}$ & $\mathrm{R}, \mathrm{N}, \mathrm{L}$ & $\mathrm{L}, \mathrm{O}$ & $\mathrm{L}, \mathrm{O}$ & $\mathrm{N}, \mathrm{L}, \mathrm{O}$ \\
\hline \multicolumn{6}{|c|}{ Democratic management style } \\
\hline 1. & Choleric person & $\mathrm{S}$ & $\begin{array}{c}\mathrm{R} \\
\text { (fragmentary) }\end{array}$ & $\mathrm{S}, \mathrm{R}$ & $\mathrm{S}, \mathrm{R}$ \\
\hline 2. & Sanguine person & $\mathrm{S}$ & $\begin{array}{c}\mathrm{R} \\
\text { (fragmentary), } \\
\mathrm{N}\end{array}$ & $\begin{array}{c}\mathrm{S} \\
\text { (fragmentary), } \mathrm{R}\end{array}$ & S, R \\
\hline 3. & Phlegmatic person & $\mathrm{S}, \mathrm{R}$ & $\begin{array}{c}\mathrm{R} \\
\text { (fragmentary), N, L }\end{array}$ & $\mathrm{R}, \mathrm{N}$ & $\mathrm{R}, \mathrm{N}$ \\
\hline 4. & $\begin{array}{l}\text { Melancholic } \\
\text { person }\end{array}$ & $\begin{array}{c}\mathrm{R} \\
\text { (fragmentary), } \\
\mathrm{N}, \mathrm{L}, \mathrm{O}\end{array}$ & $\begin{array}{c}\mathrm{L} \\
\text { (fragmentary), } \mathrm{O}\end{array}$ & $\begin{array}{c}\mathrm{L} \\
\text { (fragmentary), } \mathrm{O}\end{array}$ & $\mathrm{L}, \mathrm{O}$ \\
\hline \multicolumn{6}{|c|}{ Mixed management style } \\
\hline 1. & Choleric person & $\mathrm{S}$ & $\begin{array}{c}\mathrm{R} \\
\text { (fragmentary) }\end{array}$ & $\mathrm{S}, \mathrm{R}$ & $\mathrm{S}, \mathrm{R}$ \\
\hline 2. & Sanguine person & $\mathrm{S}$ & $\begin{array}{c}\mathrm{R} \\
\text { (fragmentary), } \mathrm{N}\end{array}$ & $\begin{array}{c}\mathrm{S} \\
\text { (fragmentary), } \mathrm{P}\end{array}$ & $\mathrm{S}, \mathrm{R}$ \\
\hline 3. & Phlegmatic person & $\mathrm{S}, \mathrm{R}$ & $\begin{array}{c}\mathrm{R} \\
\text { (fragmentary), N, L }\end{array}$ & $\mathrm{R}, \mathrm{N}$ & $\mathrm{R}, \mathrm{N}$ \\
\hline 4. & $\begin{array}{l}\text { Melancholic } \\
\text { person }\end{array}$ & $\begin{array}{c}\mathrm{R} \\
\text { (fragmentary), } \\
\mathrm{N}, \mathrm{L}\end{array}$ & $\begin{array}{c}\mathrm{L} \\
\text { (fragmentary), } \mathrm{O}\end{array}$ & $\begin{array}{c}\mathrm{L} \\
\text { (fragmentary), } \mathrm{O}\end{array}$ & $\mathrm{L}, \mathrm{O}$ \\
\hline
\end{tabular}

Symbols:

$\mathrm{S}$ - strong, $\mathrm{P}$ - average, $\mathrm{N}$ - below average,

$\mathrm{L}$ - weak, $\mathrm{O}$ - absent.

The degree of manifestation of professional sectoral personal identification (PSPI) is significantly different for managers with different temperaments and gender professional identification. In particular, with full male identification, there is a predominantly high degree of professional sectoral personal identification with different management styles. A high and medium degree of professional sectoral personal identification predominates in partial female identification. In most cases, with partial male identification, you can see that the degree of the professional sectoral personal identification is below average. Full female identification of managers is more dependent on the type of temperament.
The characteristics of professional sectoral personal identification of gender-sensitive managers will appear differently (Table 2). Of all the characteristics under consideration, let us consider the example of a classical, basic component that allows us to explore the professional aspect. Differences are also observed in other studied characteristics of the professional sectoral personal identification from a gender perspective. In men and women with partial masculinity, the characteristics predominate and are most pronounced and frequent. It should be noted that the latter, strengthening professional industry identification, significantly lose their female characteristics. 
Exploring the leaders, it is necessary to dwell on the relationship of management strategies with the degree of the professional sectoral personal identification of managers, taking into account the temperament and management styles in Figure 1. An aggressive management strategy is chosen by choleric people, sanguine persons, sometimes phlegmatic people resort to it, for which optimal and conservative management strategies are typical. The melancholic resorts to conservative manage- ment strategies, although the management style is usually determined by alternates. Hence, the degree of the professional sectoral personal identification head is negligible. Phlegmatic inherent democratic and mixed management style.

At the same time, sanguine and choleric people mostly resort to command-administrative or mixed management styles.

Table 2. The degree of manifestation of the characteristics of professional sectoral personal identification (PSPI) of managers with regard to gender factor

\begin{tabular}{|c|c|c|c|c|}
\hline \multirow{2}{*}{ Specifications } & \multicolumn{2}{|c|}{ Men's identification } & \multicolumn{2}{|c|}{ Female identification } \\
\hline & full & partial & full & partial \\
\hline $\begin{array}{l}\text { 1. The possession of certain profes- } \\
\text { sional skills. }\end{array}$ & $P$ & $\mathrm{P}, \mathrm{N}$ & $\mathrm{P}, \mathrm{N}$ & $\mathrm{P}$ \\
\hline 2. Professional thinking. & $P$ & $\mathrm{P}, \mathrm{N}$ & $\mathrm{P}, \mathrm{N}$ & $P$ \\
\hline 3. Professional self-confidence. & $\mathrm{P}$ & $\mathrm{P}, \mathrm{N}$ & $\mathrm{N}, \mathrm{F}$ & $\mathrm{P}$ \\
\hline 4. Self check. & $\mathrm{P}, \mathrm{N}$ & $\mathrm{N}$ & $\mathrm{N}, \mathrm{F}$ & $\mathrm{P}$ \\
\hline $\begin{array}{l}\text { 5. Professional motivation and } \\
\text { creativity. }\end{array}$ & $\mathrm{P}, \mathrm{N}$ & $\mathrm{N}, \mathrm{F}$ & $\mathrm{P}$ & $\mathrm{P}, \mathrm{N}$ \\
\hline 6. Professional self-development. & $\mathrm{P}$ & $\mathrm{N}, \mathrm{F}$ & $\mathrm{N}, \mathrm{F}$ & $P$ \\
\hline 7. Efficiency in business. & $\mathrm{P}$ & $\mathrm{N}, \mathrm{F}$ & $\mathrm{N}, \mathrm{F}$ & $\mathrm{P}$ \\
\hline \multicolumn{5}{|l|}{ Additional } \\
\hline 8. Self-esteem. & $P$ & $\mathrm{~N}, \mathrm{~F}$ & $\mathrm{~N}, \mathrm{~F}$ & $P$ \\
\hline 9. Self-education. & $\mathrm{P}, \mathrm{N}$ & $\mathrm{N}, \mathrm{F}$ & $\mathrm{N}, \mathrm{F}$ & $\mathrm{P}, \mathrm{N}$ \\
\hline 10. Professional skill. & $\mathrm{P}$ & $\mathrm{N}, \mathrm{F}$ & $\mathrm{P}$ & $\mathrm{P}$ \\
\hline 11. Self-inducement. & $\mathrm{P}, \mathrm{N}$ & $\mathrm{N}, \mathrm{F}$ & $\mathrm{P}$ & $\mathrm{P}$ \\
\hline $\begin{array}{l}\text { 12. Spiritual, moral, professional } \\
\text { satisfaction. }\end{array}$ & $\mathrm{P}$ & $\mathrm{R}$ & $\mathrm{P}$ & $\mathrm{P}, \mathrm{N}$ \\
\hline 13.Love to the profession. & $\mathrm{P}$ & $\mathrm{R}$ & $\mathrm{P}$ & $\mathrm{P}$ \\
\hline $\begin{array}{l}\text { 14.Preservation of } \\
\text { own individuality }\end{array}$ & $\mathrm{P}, \mathrm{N}$ & $\mathrm{R}$ & $\mathrm{P}$ & $\mathrm{N}, \mathrm{F}$ \\
\hline 15. Rationalism. & $\mathrm{P}$ & $\mathrm{N}, \mathrm{F}$ & $\mathrm{N}, \mathrm{F}$ & $\mathrm{P}, \mathrm{N}$ \\
\hline 16. Develop yourself. & $\mathrm{P}, \mathrm{N}$ & $\mathrm{N}, \mathrm{F}$ & $\mathrm{N}, \mathrm{F}$ & $\mathrm{P}, \mathrm{N}$ \\
\hline 17. Self-management. & $\mathrm{P}$ & $\mathrm{N}, \mathrm{F}$ & $\mathrm{N}, \mathrm{F}$ & $P$ \\
\hline 18. Creative potential. & $\mathrm{P}, \mathrm{N}$ & $\mathrm{N}, \mathrm{F}$ & $\mathrm{N}, \mathrm{F}$ & $\mathrm{N}, \mathrm{F}$ \\
\hline 19.Communicative control. & $\mathrm{PN}$ & $\mathrm{N}, \mathrm{F}$ & $\mathrm{N}, \mathrm{F}$ & $\mathrm{P}, \mathrm{N}$ \\
\hline
\end{tabular}

Symbols:

$\mathrm{P}$ - prevails, $\mathrm{N}$ - appears slightly,

$\mathrm{F}$ - appears fragmentary. 


\section{Discussion}

Considering management strategies in the context of professional gender identification, it should be noted that in the case of full male identification and partial female, an optimal and conservative management strategy prevails. With full female identification, these strategies are rarely used. With partial male identification and full female identification, they resort to aggressive management strategies.
Significant relationship between the degree of characteristics of professional sectoral personal identification (PSPI) and the type of profession. The classification of occupations will be used depending on the nature of the operations performed (Table 3).

- Table 3. The degree of professional sectoral personal identifi dominant manifestation cation (PSPI) of managers with respect to gender and the type of profession

\begin{tabular}{|c|c|c|c|c|c|}
\hline \multirow[t]{2}{*}{ № } & \multirow{2}{*}{ Professions } & \multicolumn{2}{|c|}{ Men's identification } & \multicolumn{2}{|c|}{ Female identification } \\
\hline & & full & partial & full & partial \\
\hline 1. & $\begin{array}{l}\text { Professions with significant physical } \\
\text { exertion }\end{array}$ & $\mathrm{S}$ & $\mathrm{S}, \mathrm{R}$ & $\begin{array}{c}\mathrm{S} \\
\text { (fragmentary), } \\
\mathrm{R}, \mathrm{N}\end{array}$ & $\mathrm{S}, \mathrm{R}$ \\
\hline 2. & $\begin{array}{l}\text { Professions of the same type of activ- } \\
\text { ity }\end{array}$ & $\mathrm{N}, \mathrm{L}, \mathrm{O}$ & $\mathrm{R}, \mathrm{N}, \mathrm{L}$ & $\begin{array}{c}\mathrm{S}, \mathrm{P}, \mathrm{H} \\
\text { (fragmentary) }\end{array}$ & $\begin{array}{c}\mathrm{R} \\
\text { (fragmentary), } \\
\mathrm{N}\end{array}$ \\
\hline 3. & Auxiliary professions & $\begin{array}{c}\mathrm{N} \\
\text { (fragmentary), } \\
\mathrm{L}, \mathrm{O}\end{array}$ & $\mathrm{R}, \mathrm{N}, \mathrm{L}$ & $\begin{array}{c}\mathrm{C} \\
\text { (fragmentary), } \\
\mathrm{P}, \mathrm{H}\end{array}$ & $\mathrm{R}, \mathrm{N}, \mathrm{L}$ \\
\hline 4. & $\begin{array}{l}\text { Professions requiring a certain level } \\
\text { of intelligence }\end{array}$ & $\begin{array}{c}\mathrm{S}, \mathrm{R}, \mathrm{N} \\
\text { (fragmentary) }\end{array}$ & $\begin{array}{c}\mathrm{S} \\
\text { (fragmentary), } \\
\mathrm{R}, \mathrm{N}, \mathrm{L}\end{array}$ & $\begin{array}{c}\mathrm{S} \\
\text { (fragmentary), } \\
\mathrm{P}, \mathrm{H}\end{array}$ & $\begin{array}{c}\mathrm{S}, \mathrm{R}, \mathrm{N} \\
\text { (fragmentary) }\end{array}$ \\
\hline 5. & $\begin{array}{l}\text { Professions that require concentration } \\
\text { of certain efforts }\end{array}$ & $\mathrm{S}, \mathrm{R}$ & $\begin{array}{c}\mathrm{S} \\
\text { (fragmentary), } \\
\mathrm{R}, \mathrm{N}\end{array}$ & $\begin{array}{c}\mathrm{P} \\
\text { (fragmentary), } \\
\mathrm{H}, \mathrm{L}\end{array}$ & $\begin{array}{c}\mathrm{S} \\
\text { (fragmentary), } \\
\mathrm{R}, \mathrm{N}\end{array}$ \\
\hline
\end{tabular}

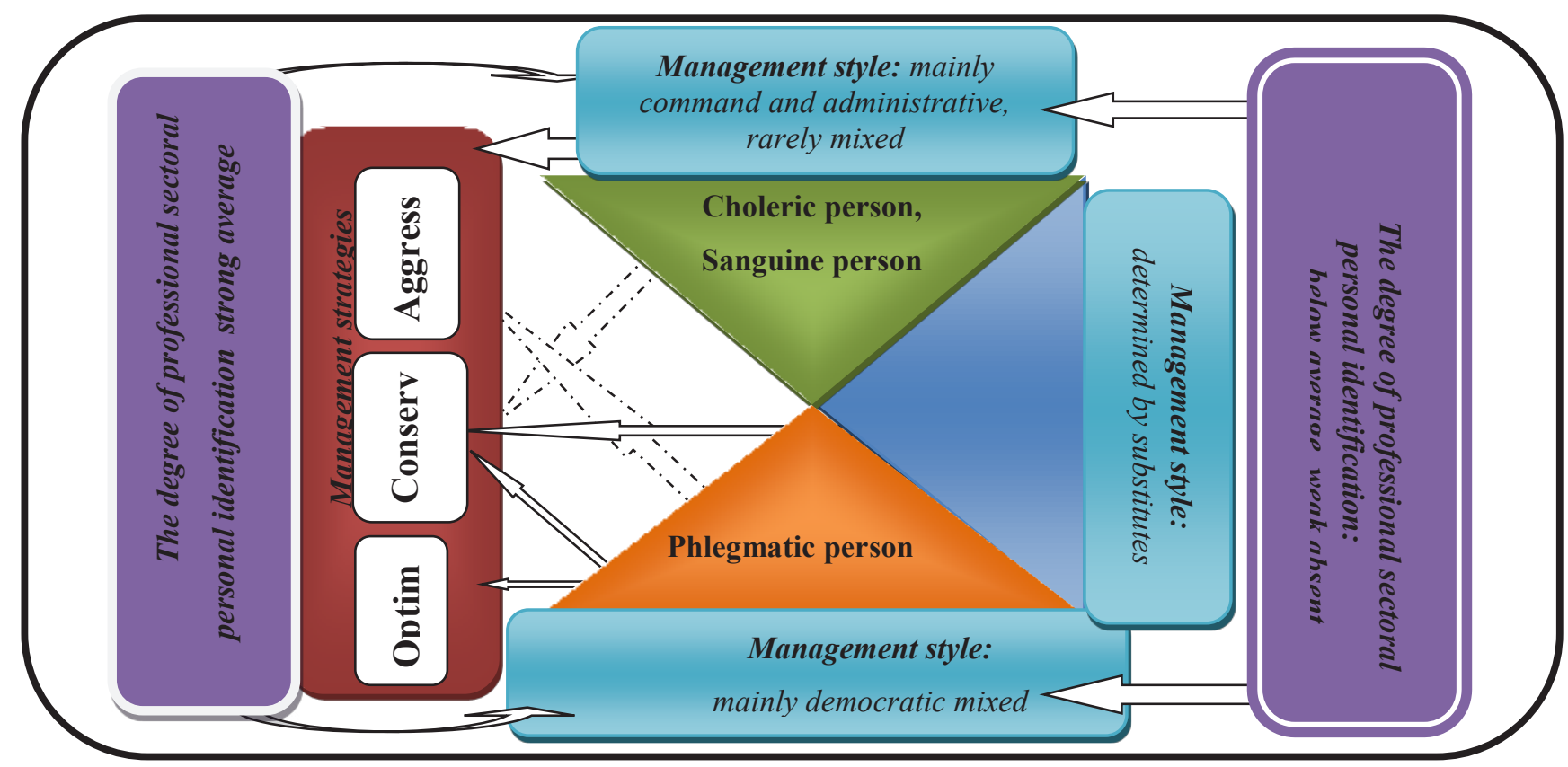

Symbols to the figure:

$\therefore:$ :-A - fragmentary manifestation

$<$ dominant manifestation

Figure 1: Interrelation of management strategies with the degree of professional sectoral personal identification of managers with regard to temperament and management styles. 
A high degree of professional sectoral personal identification is observed with full male or female identification in professions that most clearly require the implementation of gender-sensitive characteristics.

\section{Conclusion}

Considering the manager's professional sectoral personal identification, it is important to consider, in the simplest case, two main types of professional gender identification: coordinated gender identification and crisis identification. The latter may not correspond to the existing regulatory patterns and, taking into account the gender factor, may be conflicting and problematic. As part of this work, we proceeded from the coordinated gender identification of the head. Crisis gender professional identification may be due to various factors. In this case, the degree of professional sectoral personal identification may vary.

The obtained results, which showed the existence of gender differences in perceptions, allowed us to build a research strategy in such a way as to reveal these differences in behavior - in the gender characteristics of the implementation of managerial roles.

Analysis of the gender characteristics of the implementation of the managerial role confirmed the existence of gender differences.

\section{References}

1. Personnel Recruiting: Career, Personnel Management, 12, 18-50 (1998)

2. M. Wullum Nielsen, \&L. Börjeson, Gender diversity in the management field: Does it matter for research outcomes? Research Policy, 48 (7), 1617-1632 (2019) doi: 10.1016 / j.respol.2019.03.006
3. G. Berloffa, E. Matteazzi, A. Sandor, \& P. Villa, International Journal of Manpower, Gender inequalities in the industry market of young Europeans, 40 (3), 379-397 (2019) doi: 10.1108 / IJM-02-20180063

4. L. Gartzia, \& J. Baniandrés, Journal of Business Research, How feminine is the female advantage? incremental validity of traits 99, 125-139 (2019) doi: 10.1016 / j.jbusres.2018.12.062

5. K. West, D. Zimmerman, Creating gender, Reader of feminist texts. Translations Ed. E. Zdravomyslova, A. Temkina,SPb .: Dmitry Bulanin, 193-219 (2000)

6. T.A. Repina, in Issues of Psychology, Analysis of the Theories of Sex-Role Socialization in Modern Western Psychology, 2, 158-165, (1987)

7. N.K. Radin, Gender Identity, Dictionary of Gender Terms, Ed. A. A. Denisova, East-West Regional Public Organization: Women's Innovation Projects, 3133, (M .: Information, XXI century, 2002)

8. N.K. Radin, Questions of psychology, Use of gender analysis in psychological research, 2, 22-27 (1999)

9. I.S. Kon, Masculinity as a Story, The Gender Kaleidoscope, Course of lectures, ed. M.M. Malysheva, M $\therefore$ Academia, 209-228 (2001)

10. Yu.E. Aleshina, A.S. Volovich, Questions of psychology,Problems of mastering the roles of a man and a woman, 4, 74-82 (1991)

11. O.A. Voronina, Sociological studies, Woman in a man's society, 2, 43-50 (1982)

12. E. Erickson, Identity: Youth and Crisis: Per. from English, E. Erickson. 2nd ed 352-287 (M .: Flint: MPSI: Progress, 2006)

13. L.B. Schneider, Personal, gender and professional identity: theory and methods of diagnosis, 128, 38 (M $\therefore$ Moscow Psychological and Social Institute, 2007) 